\title{
LEGISLATING UNORTHODOX TAXES: THE HUNGARIAN EXPERIENCE ${ }^{1}$
}

\author{
Dániel Deák \\ Professor, Corvinus University of Budapest, Department of Business Law \\ E-mail: daniel.deak@uni-corvinus.hu
}

To date, a series of non-traditional schemes have proliferated in the area of tax law, challenging the widely accepted principles of tax legislation. Lump-sum or presumptive taxes, redemption fees or tax amnesty, corrective taxes (bank levies), or confiscatory taxes (e.g., banker bonuses) can hardly be reconciled with the hard core of tax legislation that is established on the principles of equality and legal certainty. The present paper discusses these unorthodox types of public charges.

Keywords: tax amnesty, arbitrary state, windfall gain, redemption fee, Rubik agreements, fiscal populism, balanced-budget provision, non-discrimination, proportionality, confiscatory tax, share of social burdens, reverse discrimination, protection of human dignity in tax matters, distributive justice, proper operation of law

JEL code: K34

\section{Introduction}

Law normally suggests wide acceptance. Sometimes it can happen, however, that it comes into conflict with the higher values of natural justice or the public interest. Tax law is no exception to this. Tax legislation can first be criticized for the reason that it would not reflect particular ideas of distributive justice. It is quite normal that substantive tax laws are discussed before the public. There is another - a formal - aspect of evaluating tax legislation as well. In this case, deficiencies of tax laws can be discovered as long as they are not consistent with the standards of the rule of law and, more closely, legal certainty. This is a major subject of the paper that follows.

\footnotetext{
${ }^{1}$ This paper is a further developed version of the paper prepared on the same subject and to be published by Lodz University
} 
Where it is the task to assess the quality of tax legislation according to formal criteria, it is the principles of the rule of law and legal certainty that raise public attention. It is thus not the issues of the acceptance of law, and - in the tax law area - the administration of distributive justice that come to the fore. Instead, it is clarity, consistency and predictability of legislation that are at stake. This is the guiding criteria, even if the government of a country may enjoy much elbow-room in legislation in general and, in particular, in the enforcement of distributive justice through tax laws.

In regard to the legal standards of tax legislation, the following major questions can be raised:

- what are the sources of tax law;

- what is the process of enacting tax law like;

- what are the formal criteria for the assessment of the quality of tax legislation;

- what is the relationship between national and international tax legislation; and

- what is the relationship between tax and non-tax legislation.

The above questions refer to the normal state of tax legislation. The current times however may be seen more hectic than normal. To date, a series of non-traditional schemes have proliferated in the area of tax law, challenging the widely accepted principles of tax legislation. Lump-sum or presumptive taxes, redemption fees or tax amnesty, corrective taxes (bank levies), or confiscatory taxes (e.g., banker bonuses) can hardly be reconciled with the hard core of tax legislation that is established on the principles of equality and legal certainty. In the present paper, these unorthodox types of public charges are discussed. The examples of unorthodox tax legislation will be preceded by the discussion of the legal environment, from which businesses subject to tax derive their legal status.

\section{Legal fiction and legal realism}

The quality of tax legislation and the standard of legal certainty do not have the same significance in different jurisdictions. For example, in common law counties, it is emphasized that legal rules should apply uniformly to all businesses, in whatever activities they are engaged, and wherever they operate. In civil law jurisdictions, however, it is frequently scrutinized if businesses exercise their rights properly, and in accordance with the interests of their stakeholders. 
It is not precluded in any of the above cases that a high level of the quality of law can be reached. On the European continent, the technicalities of law may still be subordinated to meta-juridical values in a number of jurisdictions. The considerations of equity and natural justice may also appear in common law systems. They may still be integrated in the process of deciding legal cases. In Europe, it is frequently emphasized that the law should be a closed system. Legislation is still the responsibility of political bodies, and lawyers themselves do not take much part in generating law.

The legal treatment of businesses may thus depend on whether a particular accent moves on the legal status that is preserved in abstract terms wherever the business entity operates or on the individual rights that can be exercised under the material circumstances determined locally. In the latter case, it can easily happen that the formal aspects of legislation and the inner harmony of a legal system are depreciated by the particular interests to be protected in the real life. The loss of immunity against non-juridical intrusion may lead to the deterioration of the quality of law that can then be sacrificed under the values delivered by unorthodox legal and tax policies. Thus, the discussion of legal nominalism and realism comes before the subject of unorthodoxy in tax law that will be dealt with subsequently.

From the standpoint of international tax law, it is fundamental to distinguish between capital exporting and importing countries. Historically, common law countries belong to the first group, and a number of countries, which can be found on the European continent, and which have developed civil law systems, to the second group. Under capital export neutrality, the tax treatment of investments should be the same, irrespective of whether they have been made within or outside the country. Therefore, it is reasonable to apply the incorporation principle for the recognition of businesses. Hence, once businesses have been incorporated, they will preserve their original legal status without regard to whether they have moved to another jurisdiction or not.

Under capital import neutrality, the legal and tax treatment of investments should be the same, irrespective of whether the they have been made by domestic or foreign resident persons. Therefore, it is reasonable to apply the principle of the effective place of business for the recognition of businesses. Hence, once business set up the effective place of management within the domestic territory, they will change their legal status, and become resident in that jurisdiction. It comes also from the above that the foreign tax credit applicable in capital 
exporting countries may neutralize differences between jurisdictions while the exemption method applicable in capital importing countries enhance the same differences (Musgrave Musgrave 1972; Musgave, 2008; Avi-Yonah, 2000).

The British and American tradition is that they have a single view of the world and, therefore, apply their domestic rules even on the developments made oversees. On the European continent, the modern nation states have succeeded absolute monarchs, being adjusted themselves to the political and economic disintegration of the world they have experienced. The universalism arising from the common law tradition has also led to the conception that law itself should be able to generate a legal status. It is thus sufficient for the recognition of businesses that they could rely on the legal fiction that they derive their status from the law given to them. On the European continent, the operation of law is not yet enough for recognition. It is also necessary that particular communities should recognize the legal status to be obtained. A company cannot be recognized only due to the intervention of law. It is also required to express the will of particular groups. Where the foundations of the civil life are strong, it is not necessarily important to enhance the will of different groups. Where, on the contrary, it is evident for citizens to organize themselves against the prerogatives of the public authorities, it does not seem to be sufficient just to refer to the abstract force of law.

Businesses can be approached from the standpoints of universalism and particularism. In the first case, the legal norm can be relied on. In the second one, it is necessary to identify the utilities a business can produce (Dewey 1926: 660). From the perspective of this universalism, or legal nominalism, ${ }^{2}$ the attributes of natural or legal persons, are determined purely by law. Then, the carriers of these attributes can be compared to each other. Therefore, the equality principle must be applied. From the viewpoint of particularism, i.e., legal realism, businesses can be identified while they exercise rights. These rights can be exercised properly or not. The latter case is the abuse of law (fraus legis) that is to be prohibited.

In the American constitutional practice, it was not possible to extend to companies the constitutional protection of human dignity. Therefore, Article IV (2) of the federal constitution on the privileges and immunities of citizens cannot apply to businesses. However,

\footnotetext{
${ }^{2}$ See: "nomina sunt juris et non personarum"; "vera persona est rei rationabilis individua substantia" (Dewey 1926: 665-666).
} 
as a result of the Twelfth Amendment, companies are also protected under the due process principle. They can thus enjoy fair treatment in the same way as citizens (Scalia 1989: 1176). ${ }^{3}$ As Justice Luis Brandeis emphasized in 285 U.S. at page 406: "Stare decisis is usually the wise policy, because in most matters it is more important that the applicable rule of law be settled than that it be settled right" (Wade 1941: 187).

From the standpoint of legal nominalism, the individual legal status is measured to the highlevel standard of equality before the law. The equal treatment of those is emphasized who are treated as equals on a high level of abstraction. In such circumstances, legal certainty is crucial since the law is the only source of determining a particular status to be compared to another one. For this purpose, law should be uniform and certain.

From the viewpoint of legal realism, it is not only important to take into account equality before the law, but also the real-life differences of the subjects of law that are otherwise treated as equal. Therefore, in this view, more emphasis is placed on the protection of human dignity, and on the particular values that animate human dignity in everyday life (respect of privacy, freedom of conscience, etc.). In this context, it is crucial what the rights of individuals are about and how these rights can be exercised. As rights cannot only be used, but also abused, the abstract principle of equality may be superseded by the more specific assessment of the exercise of particular rights.

Against the above background, it can be understood that the principle of legal certainty that is widely appreciated in modern democracies does not play the same role in different legal cultures. In the tax policy of the European continent, more emphasis is placed upon the principle of vertical than horizontal equity in many countries. In common law countries, this is basically to the contrary. The quality of tax legislation is apparently more appreciated in the latter than in the former case. In the first one, a government enjoys much elbowroom in formulating tax policy. That can be detrimental to the quality of legislation, however. In Europe, legal certainty is frequently subordinated to the consideration of the administration of distributive justice. The instrumental view of tax law threatens to erode the integrity of tax law. Tax legislation provides fewer safeguards as regards fundamental legal principles like

\footnotetext{
${ }^{3}$ For the first case, see: Paul v. Virginia [8 Wall. 168 (U.S. 1869)], for the latter: Santa Clara County v. Southern Pacific R. R., 118 U.S. 394 (1886) in Timberg (1946: 537, 539). The Equal Protection Clause epitomizes justice more than any other provision of the US Constitution, Antonin Scalia asserts.
} 
legal certainty, equality, impartiality, and neutrality, Hans Gribnau emphasizes (Gribnau 2013). Legal certainty is faded in countries that prefer discretionary fiscal policy to fiscal discipline.

\section{Tax amnesty and arbitrary state}

A fiscal government enjoys much elbowroom in a country in introducing taxes. Various taxes can be placed in fact between two extremes: the proportional taxation of transactional gains means possibly the least interference with economic decisions. Therefore, such a tax is the closest to the ideal of fiscal neutrality. On the contrary, progression in income tax is levied on the income or wealth of the rich to a larger extent than on that of the poor. The more the income or wealth to be taxed, the higher the applicable tax rate can be.

The liability to pay tax, including a progressive one, is determined by statutory law, the provisions of which are of general effect. A redemption fee that is payable once and for all represents an even more radical break with the equality standard than progression in income tax. By way of paying this fee, the untaxed income or property can be regularized, i.e., the illegal income or property can be made legal for the future. The recent example for this is the so-called stability savings account in Hungary. By means of making payment on this, the untaxed income or property can be legalized by force of law. It is thus not precluded that even dirty money can be washed white through state assistance. ${ }^{4}$

The possibility of regularizing untaxed income or property was widely available in Hungary for several years until 2013. The recent opportunity of tax amnesty was made by two sections of a law on mixed budgetary subjects, the effect of which was extended from year to year, and the contents of which have also been amended several times. ${ }^{5}$ In the following, the stability savings account as recently introduced in Hungary will be discussed as an example for tax amnesty, a subject of unorthodox tax policy.

\subsection{Stability savings account}

\footnotetext{
${ }^{4}$ Act CXV of 2013, modifying the Act CXCIV on economic stability. The modifying law inserts into the Economic Stability Act provisions on this special account. See, in particular, Sec. 39B (1-2). Interestingly, Sec. 31 (2) of the Economic Stability Act prohibits the application of tax amnesty. It is questionable how the new provisions on the stability savings account can be reconciled with this prohibition.

${ }^{5}$ Sec. $82-83$ of the Act CLIII of 2010, as amended.
} 
The main purpose of the stability savings account is that Hungarian citizens could finance the Hungarian public debt, stabilizing the state budget. This goal looks nice, but the means of achieving it seem to be doubtful. This is because in fact tax amnesty can be obtained in exchange for the payment of HUF five million into this account. ${ }^{6}$ As the amount placed on the stability savings account is deemed to be derived at the time of payment, the account owner is liberated from any obligation to square accounts for tax purposes with the amount - or rather with the source of it - paid for this account. The income that is deemed to be derived is, of course, before taxation, or at least it is not precluded that the money paid to the account has not been taxed ever. Tax is applicable to the return made on the invested capital through the stability savings account. The capital itself is considered by law to be made out of sources of income after taxation. As it can be seen, the scheme under discussion is appropriate for regularizing the capital made out of untaxed income in return for some payment into a special account. To make things worse, the release from tax obligations is bound to the condition that payment should be effectuated for public debt securities denominated and kept in HUF (whether by Hungarian or non-Hungarian financial intermediaries). This is clearly to restrict the free movement of capital.

In connection with tax amnesty, it is reasonable to take into account what fiscal neutrality is about (Epstein 1987; Murphy - Nagel, 2004), and how the redemption of tax liability in return for a one-time payment can be interpreted. It is a further question why the state that introduces tax amnesty is going to give up fiscal neutrality. Tax amnesty is the manifestation of fiscal populism. Hence, populism can exhibit itself not only in the way that special taxes will be levied on the rich, but also in the manner that special fiscal benefits are available for the middle class to be corroborated by public means. One of these is tax amnesty (Deák 2009).

\subsection{Transactional gain}

It is the inevitable problem of taxation that even in its best format it distorts economic decisions, although no one can doubt that there are public programs that must be financed by

\footnotetext{
${ }^{6}$ As Para. (1) of the above quoted Sec. 39B provides for, all the amount paid into the stability savings account by the account owner natural persons is deemed to be income derived at the time of this payment for the purposes of all the legal rules on the obligation of payment, and on all the obligations and legal consequences associated with this obligation of payment. Under Para. (2), tax is to be withheld on the income derived by the financial intermediary that keeps the stability savings account. It transfers the amount of the tax withheld to the state budget without giving any information of the account owner to the tax authorities.
} 
taxes. Disputes cannot be avoided, however, on what the methods of taxation are that distort economic decisions to the smallest extent. Effects that seem to be distorting arise from the fact that, in a situation of free trade economy, it is ideal to reach a balance on an individual scale between the supply of goods or services and the compensation payable for these. In a fiscal economy, however, equality can be interpreted on a social scale, with particular regard to the whole state budget. Even in the circumstances of a balanced state budget, it is not precluded that sharp disputes take place on the desirable directions of fiscal policy.

The power of taxation disturbs to the possibly smallest degree the operation of the free trade economy as long as the liability to pay tax relates to single transactions. Those who obtain gains from transactions, or those in respect of whom there is some value added attached to their transactions, are liable to pay tax on the increase in value. The introduction of the concept of personal income tax made revolutionary changes in the beginning of the $20^{\text {th }}$ century. In America, it was even necessary to amend the constitution, with the purpose of authorizing the federal state to provide for the liability to pay tax in a way that it would be possible to levy tax on whatever source of wealth. This is problematic in particular because while in case of single transactions it is relatively easy to grasp what is considered income or the value added for tax purposes, the concept of income becomes immediately gloomy if it is assessed based on the sum of the accretion of wealth to be derived from whatever source that can take place at a given time with a given person (Schanz 1896; Haig 1966; Simons 1970).

Where is this gloominess from? The reason from the dark side of the personal distribution and taxation of income is that it is not actually clear what is the accretion of wealth about. A simple example for these problems is the taxation of dividends. The question can be raised at what time the taxable dividends are realized. Is it the time only, at which taxable dividends are considered to be developed for tax purposes when they are declared and paid? What if they are declared, but not paid out because they will be capitalized? Then, dividends are included in the invested capital. As a consequence, the value of investment is increased that can obviously be considered for tax purposes as income. Further, one can ask whether the company profit can be taxed with the company member, on the payment of which no decision has yet been made by the owners. This question is not absurd at all. It may well occur in a number of jurisdictions that the company member has to pay tax even on the profit that has not yet been distributed. 
It is thus not crystal-clear at what time taxable income is developed. At the time when the right is developed to obtain it? Or at the later time when the owner of income has derived the proceeds in cash? Or at the time only when the income derived has been used? Can it be considered as profit that someone acquires securities through a forward contract at a price that is lower than the free market price that can be reached at the time of acquisition? Is it taxable? Or tax liability is developed at the time only when the securities acquired at a gain have already been disposed of? Maybe, at an additional gain? What will happen if the taxpayer disposes of the securities at a loss, which he or she has acquired at a gain? Can the loss compensate the taxable gain? What if the securities acquired, and disposable, at a gain are reinvested?

What if securities are acquired, but they are locked-up for a certain time period, and the owner of the securities does not have access, whether directly or indirectly, to any benefit to be derived from the frozen securities during the time of absence? Furthermore, it is assumed that the owner of securities does not have any access to securities, but the dividends derived during the lock-up period will be used to capitalize the investment and, this way increase its value. Is this increase in value taxable?

\subsection{Windfall gain}

It is a fundamental question of tax policy to find a concept of income that is comprehensive enough. This is possible if in an economy everything happens regularly. This is, however, illusionary. What to do with the extraordinary gain that is developed in extraordinary circumstances? This can be considered to be windfall gain for tax purposes. This is in fact a gain derived by chance, or a gift received unexpectedly. If investment were compared to a tree and its yield to the fruit of the tree, profit could be seen as the fruit growing from year to year. What happens, however, if the fruit can be obtained by chance, due to the fact that it has been taken away - let us say - by the wind from an unknown tree, and it can now be found in a particular garden?

In case of windfall gain, an ingenious state can discover itself a particular source of tax. The argument to be mobilized is that it is just to require that the beneficiary should share with the state the extraordinary profit derived in extraordinary circumstances. This is the basis for the introduction of Robin Hood taxes that have been so much popular in recent years. 
This tax is, of course, associated with populism: it is required to take something away from the rich, in order to give it to the poor. This sounds well, but it is not necessarily true. Citizens can see only that the state applies restrictions on big income-earners. It is not clear for what purposes the revenue obtained this way can be used. Is there anybody, for example, in Hungary who has been informed of the fact whether the revenue obtained from the Robin Hood tax that is levied on the profit of energy suppliers at an extra rate of $11 \%$ has been used for social purposes? Or at least has it been used to endow a fund that could support the maintenance and development of the energy network, or the research of alternative resources of energy?

The Robin Hood tax is apparently a means of cheap morality (Beck - Prinz 2010). The consistent policy of legislation that requires much energy can swiftly be replaced by hasty legislative instruments. The question remains, of course, at what level of quality this is possible. Such taxes are the result of the phenomenon that professional arguments are directly pushed out by political considerations. This policy can be successful in the short term. It is not good even for the actual course of policy in the long term, and certainly harmful to the society.

Robin Hood taxes belong to a series of corrective taxes (Shavell 1993; Bergfeld 2008). They can be characterized as follows:

- the primary purpose is not to achieve tax revenue, but to apply restrictions on the economic behavior that is not welcome (e.g., activity resulting in extra burden on the environment, or financial hyperactivity carrying systemic risks);

- the performance reflected in the payment of tax is compensated by the state, even if this cannot be interpreted under the laws of the market economy (e.g., the bailout of banks); and

- their introduction requires special authorization (because they challenge the democratic principle of the unity of state budget).

It is difficult to put corrective taxes into the traditional armory of fiscal policy. Under solid constitutional circumstances, it is possible to provide for the liability to pay tax within the strict framework of legality, on a high level of legal certainty. While applying corrective taxes, it is problematic that the subject of legal regulation cannot be anticipated very well, and the economic effects of their application cannot always be measured. As a corollary to it, it is 
doubtful to apply estimation and forecasting in legislation. For example, it is not possible to associate corrective taxes with risky financial activity unless the possible harms can be predicted even in monetary terms. Precise calculation is yet an expectation that can hardly be fulfilled.

It is also problematic that the liability to pay should be associated with the compensation to be made by the state, but this matching can only be made successively (i.e., the payment of tax and compensation given by the state can only be connected at a later time). For example, the cost of the bailout of banks was subsequently collected in many countries from banks by levying compensatory duties on them (clawback). ${ }^{7}$ These circumstances contradict the considerations of legal certainty: it could only be possible to introduce tax liability, bound to the conditions that are determined by law preliminarily. In order to remove legal uncertainties, those to whom these measures are addressed seek for special agreements to be made with the public authorities. ${ }^{8}$ It is still at the disadvantage of such bargaining that they challenge the equality before the law.

\subsection{Redemption fee and occasional liability to pay}

Redemption is the repeal of sins, resulting in liberation. In this sense, a redemption fee can be associated with tax amnesty: the state renounces requiring the payment of taxes, and penalties, in exchange for the fact that the taxpayer is willing to pay a special fee (and to promise to be honest in the future). Tax amnesty may be good for the taxpayer that comes to conversion, but this is bad news for the society: while public law is leveled down to the subject of bargaining, the considerations of the equality before the law and legal certainty may wither away.

The one-time payment in favor of the state budget can be considered as exceptional within the legal framework of taxation. Tax is a liability, which occurs repeatedly, and the conditions of which are envisaged by law on a high level of abstraction. The payment of a redemption fee is bound, on the contrary, to that special circumstances will be met. Payment will be made here once and for all. This is to challenge legal certainty, and the second maxim of taxation

\footnotetext{
${ }^{7}$ Dodd-Frank Wall Street Reform and Consumer Protection Act, Pub. L. No. 111-203 (H.R. 4173), 124 Stat. 1376.

${ }^{8}$ For this, see the agreement of the Hungarian Bankers' Association with the Hungarian Government, made in December 2011, following the introduction of the brutal bank levy retrospectively to 1 January 2011.
} 
introduced by Adam Smith, according to which the liability to pay tax must be safely predictable and calculable (Smith 1981).

There is no taxation without the freedom of ownership and parliamentary democracy. The former means that once the state applies restrictions on private property, it can only be complemented in a well-established form. Paradoxically, it is the respect of private property that is reflected in taxation. This is because the citizen is free to dispose of the part of his property that is not subject to tax. The later (parliamentary democracy) refers to the political nature of taxation. It has been clearly presented already in the America of the $18^{\text {th }}$ century: no taxation without representation.

Before the bourgeois revolutions, in the environment of pre-capitalism, one cannot speak about the economics of taxation. This is because the principles of the freedom of ownership and representative democracy could not come into force, only sporadically (in a monarchy of the estates, the separate ownership of commodities and the parliament that adopts tax laws already exist). In the pre-modern times, it is only the occasional liability to pay which exists. For example, in ancient Rome, tributes were levied on those who were not fully-fledged Roman citizens. Besides, it was also possible to levy on Roman citizens the occasional liability to pay, based on the census made by tributes. These liabilities were called tribute because the public charges were levied and collected in a system of public administration that consisted of three districts (i.e., of tributes). In modern economies, the second type of tributes can occur, but it can be considered as exceptional. The first type of tributes cannot be interpreted due to the introduction by the 1789 French revolution of the universal equality before the law (Weber 1922; Wittfogel 1962; Seligman 1959; Lütge 1961: 581; Häuser 1975: 15-17).

It can also happen that the tax authorities deem to disclose the increase in assets (i.e., enrichment) that is not substantiated by the income that has been already taxed. In such cases, it can occur that the tax authorities determine both the basis of tax, and the tax itself by way of estimation (namely, through the reconstruction of taxable income, following the application of circumstantial evidence). This is a particular bias from the standard of legality. Even in such cases, the taxpayer can argue that there is no letter of the tax law, on the basis of which it would be possible to levy tax. Tax avoidance cannot thus be identified unless there are legal provisions to rely on, which provide for the liability to pay tax - malum prohibitum - in 
advance, and which have been infringed on a level of statutory principles (or on that of judiciary doctrines in common law countries) at least. Despite this high standard, the methods of indirectly measuring income have proliferated in practice all over the world.

Estimation is a presumption that is rebuttable. It is a key issue how much the taxpayer is protected by law, and how easy or difficult it is for the taxpayer to prove the contrary of legislative presumption. Is the taxpayer, on whom the burden of proof is laid, only requested what can be expected in general to do from a man acting with due care, the application of the reconstruction of taxable income by the tax authorities can be justified even from a constitutional perspective.

A one-time duty can be apt not only for the redemption of past tax liability. It can also be used as tax relief, and as a means of fiscal incentives applicable upon tax competition. It can occur, for example, that the normal liability to pay profit tax can be redeemed by way of paying a duty in proportion to the net wealth of the business once a year, or by means of making a payment, based on an agreed sum instead of the normal accounting profit. Such methods can hardly be accepted in the international community, as they can be considered the means of harmful tax competition.

It can also occur that the occasional liability to pay is not associated with the troubles of the citizen, but with those of the entire national economy, and so with those of the state bearing responsibility for them. For example, it was obligatory in Germany to pay for a decade a solidarity surcharge - income tax and social charges to an increased extent -, which served as the basis for financing the development of the Eastern provinces. Such solidarity surcharges were also applied in Hungary for a couple of years, following the global financial crisis that burst out in the autumn of 2008 .

A recent example is the Cypriot bank levy, the introduction of which has stirred up general anxiety. The point to the problem is that the withdrawal of 60 or 70 percent of the banking deposits that can be said to be arbitrary is a challenge to the freedom of ownership and legal certainty. Once the levy was declared, leading politicians were swift enough in Germany and elsewhere in Europe in emphasizing that this is a special opportunity that cannot be repeated in another EU Member State. 


\subsection{Rubik agreements}

In the end of 2012, the Prime Minister of Hungary released resolution No. 140/2012 (28.XI.) on the authorization of certain ministers to negotiate an agreement between Hungary and Switzerland on the cooperation in the area of tax matters and financial markets. Switzerland had already concluded similar agreements (Quellensteuerabkommen) precisely under the same title with the UK, Austria and Germany. The first and second agreements entered into force on 1 January 2013. The third one with Germany did not, for lack of ratification on the German side. This is the so-called Rubik agreement. In the meantime, the European Commission was not inactive either. In a circular letter addressed to the finance ministers of the Member States on 5 March 2012, the commissioner of TAXUD warned against the danger of getting involved in Rubik-agreements. The Commission is of the opinion that a Rubik agreement is a means of harmful tax competition, aggravating the problem of missing transparency.

Both natural persons and businesses are allowed to take their savings to a place where the return on the invested capital is subject to low or no tax. This would not relieve a taxpayer from the obligation to report his or her income in the residence country, and pay tax there accordingly. This is stalled, however, where the financial intermediary does not disclose information of the investment to the tax authorities of the investor's residence country. The Commission has urged cooperation with the tax authorities of residence countries several times. An example for its success is the EC Interest Savings Directive. Switzerland was invited to apply the provisions of this directive, and to relax its banking secrecy rules.

The Swiss Bankers' Association elaborated in 2009 a special agreement to be concluded by Switzerland bilaterally. The two main components of it are as follows:

- the past income and property, which has not been taxed anywhere, and which appears in terms of deposits made at Swiss banks can be regularized in exchange for a Swiss lump-sum tax, should the taxpayer so decide, and the Swiss bank does not disclose tax information across the border; and

- as to the future, the taxpayer can choose between the option of low tax (in the residence country) and the delivery of international tax information, and the option of a higher tax (in Switzerland), yet without the provision of international tax information. 
The European Union exercises pressure on Switzerland to lift its secrecy rules where necessary for international tax purposes. The US has introduced the FATCA rules, ${ }^{9}$ according to which non-American financial intermediaries, including Swiss banks, are obliged to give information of non-American investments of American resident taxpayers directly to the Internal Revenue Service.

Hungary is tempted to obtain tax revenue in an area where otherwise there would be no chance for the country to collect revenue. The country should pay, however, for the revenue received this way a serious price: it should assist in the legalisation of dirty money. This is a standpoint that cannot be tenable either ethically or legally. Notably, Hungary would infringe both the EC loyalty requirement and its own effective law on the prohibition of tax amnesty. ${ }^{10}$

The option of a Rubik agreement destroys civilization: it conceals the fact that the liability to pay taxes means under the rule of law not only the payment of tax, but also the full report of taxable income. As explained by the EC commissioner in charge of tax matters in his circular letter above mentioned, respect of tax law is of higher value than the revenue collected from taxes. Legality of taxation should mean that the taxpayer's conduct is transparent both before the tax authorities and the fellow citizens. Would the state be content barely with the collection of taxes, taxation could hardly be more than a naked matter of theft.

To make things worse, when the Hungarian Government announced its intent to conclude a Rubik agreement, it mixed up two types of taxpayers with each other. Those which belong to the first group have taken money abroad from taxation. Hence, they have cheated the public. They would be helped out by a tax amnesty as channeled through a Rubik agreement. Innocent citizens belong to the second group who duly reported their foreign savings to the Hungarian authorities. They have not done so only for the reason of being honest. They want to pay the lower Hungarian tax instead of the high-rate Swiss withholding tax. The Hungarian Government does in fact want to exercise pressure on those who have not availed themselves of the amnesty opportunities advertised before. At the same time, however, the Government's declaration suggests a threat also for the innocent, as they are not able to distinguish between the legal treatments of the two different groups. Anyway, it would not be consistent with the

\footnotetext{
${ }^{9}$ Foreign Account Tax Compliance Act, 111 Cong. Rec. S1635-36 (17 March 2010), as amended.

${ }^{10}$ Act CXCIV of 2011 on economic stability (as amended), Sec. 31 (2).
} 
principle of the free movement of capital either to tax investments for the sole reason that they have been made across the border.

\subsection{Arbitrary state}

Tax amnesty is a break with the standards of normativeness and neutrality. As the state is eminent in organizing political and social life, it should obviously be impartial. The basis of the rule of law is, however, that the source of political power can only be the law, the provisions of which are reasonable and predictable. A rational state is expected to be impartial in the context of the rule of law. Measures like tax amnesty that deviate from the normative basis of social regulation are apt to demoralize the state. A populist state does not serve its citizens by acting in a fair and predictable procedure, but it is engaged in providing protection by way of public authority to politically selected groups of the society and the economy.

Tax amnesty is prevalent in the commercialization of the morals. A populist state that advertises the course of the so-called labor-based society promises people to get easy access to financial values on a large scale in the short run. Rights should only be allocated to those who prove to be reliable, showing up the conspicuous material signs of their economic performance. People are deserved to be respected as long as they obtain material goods. The absolute respect of human dignity is condemned as idealism and fantasy. The holders of political power decide cases by force, and do not believe in the possibility of making compromises.

Tax amnesty is launched by a state that appreciates the goods which have financial value, and the holding of which is exclusive. The benefit that can be obtained by tax amnesty is precisely this type of good: the state collects short-term revenue and the citizen availing to tax amnesty will get rid of penalty. In a mass-democracy maintained be a populist state, it is of no interest what will happen next day to the citizen that has availed to tax amnesty and to the state that has launched tax amnesty, and its citizens.

The opportunity of tax amnesty is addressed to those who think of easy and short-term solutions. A contradiction of tax amnesty-related policy cannot be avoided, however: although the state promises to clear the vices of the past, it does so for the reason only that those who have chosen amnesty should not commit vices any longer. It is not realistic, however, to expect the respectful conduct of those who have already merged into the black 
economy a long time ago. The direct benefit the state can obtain with launching tax amnesty is the revenue collected from the redemption fee. In the long run, however, tax amnesty will surely erode the overall standards of law and ethics.

\subsection{Tax amnesty as a means of fiscal populism}

Taxation is per definition a bias. It may be expected, however, that the distorting effect of taxation on economic decisions is minimized in practice. From this perspective, proportionality in taxation can be preferred where the tax burden is in proportion to the taxpayer's ability-to-pay. Progression in taxation is an alternative to proportionality. In this instance, the tax burden may be increased steeper than the taxpayer's capacity to pay tax. This is to thwart the ideas of equality, and neutrality. It is aimed, however, at reaching more material equality after taxation.

The idea of lump-sum taxes goes even further. Departing from the normative structure of the liability to pay tax, these taxes also challenge the principle of legal certainty. Lump-sum taxes, presumptive taxes, redemption fees and similar fiscal schemes erode the hard core of fiscal legislation, that is, the second maxim of Adam Smith on the certainty of tax liability. Tax amnesty is on edge with the design of the legal basis of tax liability. Tax amnesty provides an extra opportunity for a specified group of taxpayers to pay an amount in exchange for the release from common tax liability.

In the recent years, Hungary has been eminent in advertising tax amnesty. The policy of tax amnesty must be criticized, however. As tax amnesty is a means of regularizing illegal property or income, the state itself serves in fact as an assistant to money laundering. This policy may not only be disruptive to taxpayer discipline, but may also adversely affect the state itself. By introducing amnesty, the state fails to respect the social compact that would provide a guarantee for fiscal neutrality and the non-arbitrary way in which public matters are to be dealt with. Giving privileges through tax amnesty to the middle class that is to be corroborated by public means is a clear manifestation of fiscal populism.

Tax amnesty cannot be accepted unless it does not only give release from vice, but it also contributes to the consolidation of the rule of law as to the future. It should not only suggest freedom from punishment, but also from the vice itself. Tax amnesty can also be expected not only to provide freedom to individual taxpayers, but also to the community of taxpayers by 
strengthening the respect of equality before the law. A populist state that applies tax amnesty is not only partial, but even discriminative as far as it excludes those from public benefits who are not able, or willing, to adjust themselves to the requirements as provided for by extraordinary official policy.

\section{Balanced-budget provision and conditional levy}

It is reasonable to set up a fiscal rule that requires a balance of the public budget. According to it, once public debt reaches a critical level of the gross domestic product, e.g., half of it, new taxes must be levied to fill the budgetary gap. A recent example for the application of balanced-budget rules is Hungary that introduced a fiscal rule that seeks to stop increasing public debt. Such a rule is known in the German-speaking countries as "Schuldenbremse".

In Hungary, a fiscal rule on applying a special levy was included in the constitution. ${ }^{11}$ It provides for that, as long as the public debt exceeds the half of the total gross domestic product, where, due to a decision made by the Constitutional Court, the EU Court of Justice or other public authorities, the state is obliged to make a payment that is not sufficiently covered by a sum as envisaged in the central state budget, a contribution shall be introduced that is exclusively designed both in its contents and name to meet the public needs, relating to meeting this obligation. The liability to pay is only due as the case arises, and only depending on the state budget not being balanced enough. This conditional levy is an extraordinary type of fiscal obligations. It is worth discussing, the way in which it departs from the standards of fiscal policy, and whether it can be justified in the light of the well-established principles of the equality before the law and legal certainty, which should guide tax legislation at all times. This discussion follows below.

\subsection{Justification by the public interest}

The extraordinary liability to pay a levy if necessary may be a significant burden for citizens, distorting economic decisions. In this sense, this obligation restricts the freedom of citizens and enterprises. It can be justified, however, by the public interest. Still, it seems difficult to do so in this case because the public interest is of hypothetical nature. That is, the liability to pay is conditional. In normal circumstances, there is no case of emergency, although it cannot

\footnotetext{
${ }^{11}$ Article 37 (6) of the Fundamental Law of Hungary (as amended). This balanced-budget provision was repealed by the Fifth Amendment to the Fundamental Law with an effect of 1 October 2013.
} 
be precluded that there will be no compulsion in the future. It is still questionable whether, in a state governed by the rule of law, it is really in the public interest that the possibly adverse consequences of later judgments to be made by the national government could be automatically passed over to taxpayers beforehand. Doubts cannot be lifted that the government and the legislator of the balanced-budget provision are going to shift off the political responsibility, which is a plain infringement of the rules of political democracy.

The application of the conditional levy deprives the addressee of the law and, this way, the democratic public, of the possibility that a court decision could contain alternatives. That is, the court in charge does not have in fact anything to decide on the merits of the case under dispute, or it cannot decide on the financial outcome of the case. It is also doubtful whether the government in question has acted in good faith if it believes that it can get rid of the financial consequences of a judgment made in disfavor of it. Such a conduct of the government in service is explicitly in violation of the loyalty requirement as enshrined in Community law. According to it (Article 4 TFEU), a Member State shall refrain from any measure which could jeopardize the attainment of the Union's objectives.

The introduction of the conditional levy could be justified by referring to the fact that, in the recent years, some developed countries introduced in their constitutional order balancedbudget provisions. Exceptions were always made against this fiscal rule, however, with regard to emergency cases like natural catastrophes, civil war, etc. The strict prohibition of exceeding the balanced-budget standard does not seem to be well-reasoned in cases where the balance of budget is only jeopardized by the fact that the state may lose in litigation. The countries in which the balanced-budget provisions were introduced did not avail themselves of the opportunity of applying a conditional levy. This can be traced back to the reason that the balance of the budget can be preserved not only by levying new charges, but also by a reduction in public expenditures.

The application of balanced-budget provisions has generated disputes among economists as well. On a Keynesian basis, it is doubtful to artificially set up a limit on such a high level of abstraction. The reason for this is that such a fiscal rule can be an impediment to efficient supply-side economic policy. Even if from an economic standpoint it would be possible to defend the introduction of such a constitutional barrier, it cannot be taken for granted at all in what legal form such a fiscal rule could be implemented. 


\subsection{Non-discrimination and proportionality}

The restriction of fundamental rights can be justified by referring to the public interest. It is still also required that restrictive measures do not result in discrimination, and the means mobilized in the law should be in proportion to the legislative objectives. As it comes from the special nature of a conditional levy to be introduced to reach a balanced budget, there is no knowledge beforehand how it will be determined whether it is actually necessary, and what would be the specific conditions of introducing both in its contents and name a contribution that is explicitly designed to finance the public needs in relation to the state's obligation to reach a balanced budget.

Who would be liable to pay? On what basis (property, income, or anything else)? Would there be relief opportunities? Who would collect the revenue from the contribution? And so on. It may lead to arbitrary discrimination that certain groups of taxpayers are exempted from taxation without good reason or, on the contrary, a poll tax or similar burden would be uniformly levied without regard to the personal circumstances of taxpayers. It is a problem in the latter case that the legislator does not treat the addressees differently from each other with regard to the differences that exist between them in circumstances (reverse discrimination).

The proportionality principle may raise even bigger difficulties. This problem can usually occur if the law that provides for restrictions is not specific enough, i.e., the applied legal provisions are not sufficiently targeted. As a conditional levy cannot be, of course, specific, it is not yet a proper subject of assessment, taken by itself. It is still difficult to claim that basic constitutional values should be restricted simply for budgetary reasons. In case of such a conditional levy, the values of the freedom of ownership and of the rule of law are subordinated to the aim of balancing the state balanced budget, and even this is made in advance, irrespective of later consequences. It has yet been a solid practice of the EU Court of Justice that the restriction of fundamental freedoms cannot be justified solely by the loss of tax revenue or the balance-problems of the state budget. ${ }^{12}$

Further, the effect of a judgment of the EU Court of Justice cannot be restricted unless the affected Member State is successful in proving that it has to face the risk of serious budgetary

\footnotetext{
${ }^{12}$ See, e.g., C-264/96 ICI, ECR 1998, p. I-4695, Para. 28.
} 
imbalance, and otherwise it has acted in good faith. This way, it would be possible to ask the EU Court of Justice to provide grace terms by authorizing the said Member State to apply the measure which has otherwise been found inconsistent with Community law transitorily. ${ }^{13}$ It is still doubtful if a government acts in good faith that introduces a conditional levy. This is because such a government counts in advance on the fact that it does not assume responsibility for the financial consequences of a judgment made against it.

\subsection{Empty professional contents}

It cannot be the sole purpose of taxation to secure revenue. The provision for the liability to pay in favor of the public must be organically close to the requirement that after taxation noone can be worse off and, more importantly, the existing social differences should be mitigated. Taxation should contribute to the reconciliation of conflicting interests as well. Good tax policy is a means of maintaining, or even improving solidarity among social groups. All these considerations are missing when the above-mentioned conditional levy is in application.

The constitutional scrutiny of a conditional levy depends actually on the fact whether it can be compared to the standards of human dignity and of the equality of citizens before the law. Human dignity requires that the tax burden should be adjusted to the individual taxpayer's ability-to-pay, and also that the tax liability should be as small as possible, and it should affect economic decisions to the possibly slightest degree. A conditional levy is far from being attached smoothly to the taxpayers' decisions. As it is almost impossible to make preparations for a conditional levy, it is in breach of the legitimate expectations principle as well. A newly introduced fiscal instrument should contribute to the strengthening of the consistency and cohesion of law. An occasional obligation to pay threatens the integrity of law, however.

\subsection{Encroaching upon democracy}

The application of a conditional levy, being a particular manifestation of a balanced-budget rule, is a "carte blanche" for any government that is in service. It is based on a universal authority to act that makes an excuse to the authorized government for the introduction of a new fiscal measure. This may lead to the restriction of discussing the matters of fiscal policy. This is in turn an encroachment upon democracy, which is unacceptable.

\footnotetext{
${ }^{13}$ C-290/05 Nádasdi and C-333/05 Németh, ECR 2006, p. I-10115, Para. 63.
} 
It is a further effect of the application of such a levy that the balance of powers can be broken. Paradoxically, the obligation to apply a balanced-budget rule and introduce a conditional levy seems to be a constraint on the freedom of action of the government in service. This is because the government must take a decision without deliberation, in order to preserve the balance of budget. The consideration of a balanced budget does not seem to be sufficient, taken by itself, however, for the justification of taking serious restrictions as the political contents of the goal of budgetary balance are empty.

Further, the conditional levy encroaches upon the power of legislation, infringing the principle that has been respected since the monarchy of the estates for several centuries that the parliament should be free to pass tax laws. Eventually, such a conditional levy also makes a breach of the sovereignty of judges because it relates itself to a judgment in a distrustful way. Whatever the court decision is, its consequences can automatically be passed over to taxpayers without legal or political risks. This is a situation that cannot be called "comme il faut". Will this levy be in fact introduced in Hungary at a future time, it can hardly meet the challenges arising at international forums either. The European Commission has already given signs of its doubts.

\section{Confiscatory tax}

The introduction of a confiscatory tax cannot be considered as a normal instrument of fiscal policy. Such an instrument is called as a tax, but in reality it suggests creeping expropriation. Although expropriation is not precluded even under the rule of law, taxation cannot serve as an appropriate means of it. Hungary introduced a special tax at a rate of $98 \%$ on the income exceeding the statutory threshold of HUF two million per annum to be derived from severance payments made in the public sector inter alia to civil servants. ${ }^{14}$ The said provisions are applicable retroactively to the income received as of 1 January $2010 .{ }^{15}$ There have been several cases, in which the European Court of Human Rights (ECtHR) condemned this Hungarian tax, ${ }^{16}$ basically holding that it is violation of the freedom of ownership. ${ }^{17}$ As the

\footnotetext{
${ }^{14}$ Act XC of 2010 on the adoption and modification of certain economic and fiscal laws (as amended), Sec. 812.

${ }^{15}$ The problem that tax law is applicable retroactively or retrospectively, can be seen as a major deficiency of tax legislation. It is not discussed in this paper, for more details see Deák (2013).

${ }^{16}$ N.K.M. v. Hungary, No. 66529/11, Strasbourg, 14 May 2013, Gáll v. Hungary, No. 49570/11, Strasbourg, 25 June 2013.
} 
ECtHR judgments do not have general effect, it was not necessary for Hungary to repeal the legal provisions under criticism. ${ }^{18}$ In what follows is to discuss how this means of unorthodox tax policy undermines fundamental principles of constitutional value. In particular, this special tax is in breach of the principles of the freedom of property and legal certainty, as discussed below.

\subsection{Taxation, ownership and the share of social burdens}

Taxation is the means of sharing the social burden among citizens. From a constitutional perspective, the point of taxation is that the state that exercises the power of taxation recognizes private property. Anyway, the state is only allowed to tax property that does not belong to it, that is, to tax private property. The problem of the state socialist political and economic system was precisely that the major player of the national economy - that did not recognize private property and capital markets - was the state-owned enterprise, the taxation of which was still not obvious. On the contrary, the state could not claim through its authorities that exercised the power of taxation, but as an owner of the means of production to withdraw the major part of the value added that was produced by its enterprises. This was plainly manifested in the former German Democratic Repulic that did not apply taxes (Steuern), while centralizing the income produced by enterprises, but used also duties or tributes (Abgaben) that could not be placed in a normative order of redistribution. The Soviet system of economic control did not recognize the taxation of the profit of enterprises either. Instead, a system operated, in which the central allocation, and calculation, of profit (отчисление от прибыли) took place through administrative means (Rumjancev 1982).

The idea has been entertained since the termination of the centrally planned economy that one could get rid of the problems associated with the state intervention. The non-conformist instruments mobilized by the current populist Hungarian Government seem to show a break with the laws of a market economy. Example for this are the application of confiscatory taxes, the withdrawal by administrative means of the savings of private pension funds, the supersession of effective bank loan contracts by way of introducing a law subsequently on the

\footnotetext{
${ }^{17}$ Article 1 of Protocol No. 1 of the European Convention on Human Rights (signed at Rome on 4 November 1950) on the peaceful enjoyment of possessions.

${ }^{18}$ Taxpayers are not prevented from making self-audit within the five-year period of the statute of limitations. Would there be a dispute between the taxpayer and the tax authorities, the case can be decided before the court. The legal case covered by a final judgment can in turn be referred to Strasbourg where it would be likely that ECtHR would follow its line started in earlier cases.
} 
possibility of final repayments, the application of crisis taxes and Robin Hood taxes, or the administrative regulation of the energy prices payable by consumer households.

As ownership is the product of social convention, owners have to face barriers arising from the social network where ownership is recognized. The social cost of the exercise of individual rights cannot be eliminated. It must be born by the society, including the owners of private property. A basic form of the share in the public burden is taxation. It does not suggest only obligations, but also the legal condition, according to which obligations can be levied by the state. The tax legislator has to find a balance between the provision for the social burden and the ways and means of the individual restriction of the freedom of ownership. Taxation is apparently constrained by the fact that it is not decent for the state to withdraw half of the profit, or even more, that can be derived from the management of the means of property. Were it required for the state to oblige its citizens to an unusually large extent to make financial contribution, it should prefer a non-tax instrument of social control.

Extraordinary cases can happen. For example, as an aftermath of the global financial crisis that started in the autumn of 2008, the UK and France introduced taxes on the bonuses of the executive officers of financial enterprises at a rate of more than 50 percent. In Hungary, such a tax has been levied on the income to be derived from severance payments made in the public sector. It has turned out in individual cases, however, that the Hungarian state availed itself of a legal instrument that has not proved to be consistent with the European Convention of Human Rights (ECHR). The Hungarian Constitutional Court dealt with this tax two times as well (Deák 2011). ${ }^{19}$

\subsection{Reverse discrimination}

The income that is subject to the $98 \%$ special tax can be derived from the relationships covered by labor law. It is then problematic that labor law provides for mechanisms, the operation of which is impeded by tax law. Under labor law, severance payments cannot be avoided if the conditions for them are met. These payments do not make much sense, however, if the income, derived from it is withdrawn by a confiscatory tax. Tax law has been defective in the context of the $98 \%$ special tax. Tax legislation is in this respect not consistent with the proportionality principle.

\footnotetext{
${ }^{19}$ 184/2010. (28.X.) AB, 37/2011. (10.V.) AB.
} 
The conditions for the acquisition of income are developed in legal relationships that are in full accordance with the respective labor law. Tax law interferes with this development in a way that the income derived above a certain statutory threshold is taken away by tax without regard to distinguishing treatment between the cases of income derived below or above the statutory threshold. This is to treat different cases uniformly, i.e., reverse discrimination occurs. $^{20}$

According to the law on the special income tax, it is barely a matter of quantities as to whether the special tax is applicable to the income derived. This legal justification does not seem to be sufficient for constitutional purposes. This is why, in addition to the Hungarian Constitutional Court, ECtHR also concluded that the proportionality principle is infringed by tax law. ${ }^{21}$ More precisely, the instrument chosen by the legislator is not in accordance with the legislative goal. Notably, the question is here not whether the legislative goal can be accepted.

The standard for constitutional scrutiny is not material, not being related to the substantive justice to be administered by the special tax. It may be all right with this conception of justice. The problem of both the Hungarian and European courts is that the chosen instrument is not consistent with the legislative goal. This is the issue of formal law. The quality of tax legislation is eventually a formal law matter. It may seem to be paradoxical that the quality of law is to be examined in this respect from the viewpoint of formal considerations. It is nonetheless a matter of quality if legal provisions suffer from inconsistencies, although deficiencies can be pointed out irrespective of the fiscal policy the legislator may pursue.

\subsection{The principles of the protection of human dignity and non-discrimination}

Disputes on taxpayer rights are usually associated with the positive rights to a fair trial and property, and the negatively based rights of non-discrimination and non-interference by the public authorities with privacy. Further, the legislator, while approaching human beings, can enhance

- the protection of privileges and immunities, and

\footnotetext{
${ }^{20}$ As discussed in: 184/2010. (28.X.) AB, Para. III.5.3.

${ }^{21}$ Case No. 66529/11, Paras 71, 72, 75.
} 
- the standard of due process.

In the first case, the respect of human beings is interpreted from the perspective of a theory of realism, meaning the identification of particular communities and their interests in expressing mutual recognition and solidarity. In the latter case, social problems are managed from the perspective of the application of the due process clause. In that instance, the right to fair trial and the standard of equality are highlighted, and placed in a system of the rule of law. This way, a sort of universalism is developed, and emphasis is placed on the standard of the equal treatment before the law.

Dignity and equality are of systemic nature, being invoked in cases only where individual rights cannot be called upon. The protection of human dignity is close to the particular right for the protection of privacy. It cannot be considered as an individual right, however. For constitutional purposes, it is a framework, in which particular rights and obligations of citizens and enterprises, and also the particular measures of State intervention, can be evaluated.

Dignity is an end in itself that appears as absolute respect. It is part of the intimacy of human beings that must not be made contingent on performance of any duty. It represents a value that is innate in the capability of acting, based on free will. Dignity is not a matter of duties and responsibilities. Instead, it may reveal itself in a space for the realization of the self that envisages an individual person as the object of his or her reflective consciousness.

Dignity suggests the substantive aspect of justice. While equality can be presupposed by the right choice of procedures, dignity concerns distributive justice. Taxation can also contribute to the protection of dignity, provided that it can be justified by the values of either efficiency or equity. The application of economic efficiency to taxation ensures a taxation policy that can be substantiated by the general benefit the organizations of the State can provide to the individual. In this respect, it can be explained why the exercise of ownership is subject to constraints. Although the State interferes with private property, it normally complies with the idea of neutrality. According to it, taxation should avoid causing biases in economic decisions. The application of equity to taxation envisages the sacrifice a member of the society is obliged to offer. Therefore, neutrality cannot be tolerated where social imbalances 
reach a critical level. The liability to pay tribute to the community is to be constrained by the protection of dignity, however.

Making a review of the $98 \%$ special tax on income, the Hungarian Constitutional Court sporadically refers ${ }^{22}$ to the standard that the state should treat its citizens equally (i.e., equals equally) in cases where it distinguishes between taxpayers

- receiving income from the public or private sector;

- deriving income that exceeds a statutory threshold or not; and

- obtaining income in 2010 or later, or acquiring income before 2010, to which the special income tax could only apply if it were acceptable that the law on that would be applicable with a retroactive effect.

If the lawfulness of the taxpayer's conduct is examined in individual cases only, one can draw significant conclusions. This way, it is yet possible only to arrive at the statics of law. The dynamics of law can only be explored by preferring a systemic approach. For example, a court may compare an individual case to the standards carved out from a series of earlier cases. For the Hungarian Constitutional Court, it would also be possible to go beyond the realm of particularities, provided that it would be able to animate the equality principle that can be found not only in national, but also in international law as a widely recognized principle of law.

The equality principle is a sharp weapon during a constitutional review, given that tax legislation is expected to show cohesion. While there is not much elbowroom for the scrutiny of the tax law that negotiates vertical equity (Musgrave 1959), it is not so with horizontal equity (Musgrave 2008). As to the former case, fiscal policy determines the accents of the enforcement of distributive justice. Even if the principle of the general share of the public burden is enshrined in the constitution, there can be many reasons for the government in charge to give special meaning to this principle (Happé - Gribnau 2007). ${ }^{23}$

In the latter case, consistency of legislation can be required. In respect to the protection of human dignity that serves as a framework for particular values, like the respect for privacy or

\footnotetext{
${ }^{22}$ 37/2011. (10.V.) AB, Para. II.3.2.

${ }^{23}$ As the Dutch Supreme Court does not test statutes against the principle of ability to pay, it cannot test against the principle of vertical equality either, which is an element of the former.
} 
freedom of conscience, the substantive aspect of distributive justice, or rather the consideration of distributive justice, strictly speaking, can be highlighted. In regard to equality, the logic of procedural justice emerges. Over the span of the recent decades, the latter has grown in its importance. This way, the cohesion of tax legislation has been all the more critical.

\subsection{Issue of distributive justice versus a matter of the proper operation of law}

The values that can be discovered from the directions suggested by the administration of distributive justice and the proper operation of legal mechanisms, may set limits on the exercise of state power, including tax legislation. In the first case (i.e., in case of formulating distributive justice), the state still enjoys much more freedom than in the second case. That is, the government in service may widely appreciate how the substantive values of distributive justice are to be pursued. This is not the case with the infringement of the equality principle that results in deficiencies in the law itself (i.e., in the proper operation of the law). Law cannot survive unless it appears as a system that comprises rules, which are consistent with each other, and which approximate cohesion. These features of law suggest a discipline that is effective among other things for tax legislation.

If the legal dispute identified concerns itself with a problem of distributive justice, it is not enough just to refer to the protection of human dignity. This is because the latter represents a value that is too abstract and speculative. It must be enlivened by the particular values of the protection of privacy, the freedom of conscience or the guaranteed rights of citizens. For fiscal law purposes, it is even required to be more specific. Therefore, it should also be examined to what degree economic and social rights can be enforced in a legal order. It is not by chance that the freedom of ownership and the right for social security have been invoked in the ECtHR instance.

The Hungarian constitution in effect prevents the Constitutional Court from raising the principle of equality in tax matters because it is prohibited to review tax laws unless they are directly connected with the protection of human rights. ${ }^{24}$ This is serious restriction on the

\footnotetext{
${ }^{24}$ Article 37 (4) of the Fundamental Law of Hungary (as amended) provides, that as long as public debt exceed half of the gross national product per annum, the Constitutional Court is not entitled to review the constitutionality, and annul due to its infringement, of the laws on the central budget and its implementation, on national taxes, on duties and contributions, on customs and on local rates, only in the context of the right to life
} 
constitutional scrutiny of tax laws. To be worse, the standard arising from the protection of the human dignity cannot be substantiated by referring to the freedom of ownership and the right for social security. As the examination of the proper operation of law is precluded and the protection of human dignity cannot be animated by particular economic and social rights, currently it cannot be expected that tax legislation could be subject to effective constitutional review in Hungary. This means that an important pillar lacks in the system of checks and balances, ensuing the deficiency of both the rule of law and political democracy, the importance of which goes beyond taxation.

\section{Concluding remarks}

As discussed in this paper, tax amnesty makes it impossible for public authorities to act impartially, as it violates the equality before the law principle and debilitates legal certainty. Further, the balanced-budget provision on a conditional levy makes a threat for the balance of powers. This way, it encroaches upon democracy. Finally, confiscatory taxes undermine the respect of property, a fundamental value of a country's constitutional order. It also corrupts the good operation of a national tax system as long as the direct state interference with private matters appears in the disguise of taxes. In a world without unorthodoxy, no form of taxation as discussed in this paper can occur.

The number of examples for unorthodox taxes has in Hungary reached a level, above which one can conclude that these taxes have already constituted a new system of taxation. Progression has been thrown away in Hungary. This is yet inconsistent with the ability-to-pay principle, and in broader terms, with that of fairness in taxation. Strictly proportional taxes, focusing only on earned income, but neglecting the taxpayer's social environment, hit the poor because they have to spend a higher portion of their wealth to meet the liability to pay tax than the rich.

It seems reasonable to expect that social differences should not be bigger after taxation than they were before taxation. Proportional taxes disregard this consideration. As a consequence

and human being, the protection of personal data, the freedom of conscience and religious belief, or of the rights connected to the Hungarian citizenship. The Constitutional Court is authorized to annul even the laws falling within the above scope without limitation, provided that the criteria that apply to the creation and promulgation of these laws, as determined by the constitution are not fulfilled. 
of the application of proportional taxes, the poor will be all the poorer, and the rich will be all the richer. This is not favorable for the purposes of maintaining social harmony.

Under unorthodoxy, the function of taxation is reduced because taxation policy is purely adjusted to the logic of the exchange in simple material values. More sophisticated thoughts on social balancing and justice are neglected. They would be based on the idea that taxation should do correction in the relationships as developed in the course of market-oriented transactions. Unorthodoxy focuses, on the contrary, on those who are able to acquire material goods, and those who are unable for any reason remain out of the scope of public attention. This is a bad message for the purposes of taking care about social security.

As the country is an importer of capital, the Hungarian Government would like to expedite savings. Therefore, as long as the income earned is not consumed, people are not punished by taxes. For lack of the application of progressive tax rates, the Government has still to face a remarkable loss of revenue. In order to approximate a budgetary balance, it seeks to compensate the losses it has suffered for lack of tax progression by laying stress on indirect taxation.

It is lucky that VAT is neutral. Although it lays much burden on enterprises, it does not distort economic decisions. This is not the case with special industry levies (bank levy, financial transaction duty, telecom tax, energy supplier's Robin hood tax, pharmaceuticals' contribution, retail store tax, etc.), however. They do not only represent a high burden of taxation, but they also lack neutrality. The combined effect of the large volume of taxation and missing neutrality is that taxation constitutes a major barrier to investments and, eventually, economic growth.

The Hungarian tax policy that lays stress on indirect taxes and, in particular, on special industry levies suffers from two major insufficiencies: it fails to meet the requirements of both fairness and neutrality. This is strange because once a country is weak in fairness, it achieves neutrality in taxation and, vice versa, where taxation lacks neutrality, it may be aimed at fairness. This is not true for unorthodox legal and tax policies. Such a tax policy does not seem to be able to survive in the long run, however. At the same time, unorthodoxy is also responsible for undermining democratic procedures and the mechanisms of the rule of law, as shown through a number of examples above. 
There is an inherent contradiction in the course of tax policy followed under unorthodoxy. The principle of fairness in taxation is forgone, being subordinated to the idea that those who earn must not be punished by taxes. It is not yet able at the same time to support the development of the market economy because the state interferes with economic decisions both by special industry levies and non-tax related administrative measures. The selected groups of the middle class should be protected by administrative means against competition with foreign enterprises. This entails still demolishing instrumental rationality that would maintain market-oriented decision-making.

Unorthodox tax policy is aimed at applying the fiscal incentive that someone is not taxed as long as his/her income is not withdrawn for consumption. Lack of sufficient capital makes a harsh constraint on economic growth, however. This problem can be managed for a certain time by state intervention. Focus is then made on current problems. Long-run considerations are neglected. For lack of competition and pluralism, the political system is not able to provide mechanisms which would compel correction of this short-sided policy. This inevitably leads to a situation where the future is devoured.

The double insufficiency of injustice and arbitrariness cannot be managed, only in the short run. Real problems can thus be hidden for some time. There is no solution for striking a balance in the long-term, however. Unorthodoxy is a policy of the current time, allured by the very moment. As it does not contain mechanisms of self-correction, it is blind to the future. This is more than disquieting.

\section{References}

Avi-Yonah, R. S. (2000): Globalization, tax competition, and the fiscal crisis of the welfare state. Harvard Law Review 113(7): 1575-1648.

Beck, H. - Prinz A. (2010): Moralisierung in der Steuerpolitik: Was taugen die jüngsten Steuervorschläge? Wirtchaftsdienst 90(12): 818-825.

Bergfeld, K. (2008): Lenkungsabgaben im europäischen Finanzrecht. Baden-Baden: Nomos.

Deák, D. (2009): Hungary's half-way tax amnesty. Tax Notes International 53(7): 603-607.

Deák, D. (2011): Pioneering decision of the Constitutional Court of Hungary to invoke the protection of human dignity in tax matters. Intertax 39(11): 534-542. 
Deak, D. (2013): Hungary. In: Gribnau, H. - Pauwels, M. (eds): Retroactivity of tax legislation. Amsterdam: European Association of Tax Law Professors, pp. 289-307.

Dewey, J. (1926): The historic background of corporate legal personality. Yale Law Journal 35(6): 655-673.

Epstein, R. (1987): Taxation in a Lockean world. In: Coleman, J. L. - Paul, E. F. (eds), Philosophy and Law. Oxford and New York.

Gribnau, H. (2013): Equality, Legal Certainty and Tax Legislation in the Netherlands; Fundamental Legal Principles as Checks on Legislative Power: A Case Study. Utrecht Law Review 9(2): 52-74.

Häuser, K. (1975): Abriß der geschichtlichen Entwicklung der öffentlichen Finanzwirtschaft. Tübingen: J.C.B. Mohr.

Haig, R. M. (1966): The Concept of income. Economic and legal aspects. In: Musgrave, R.A. - Shoup, C.S. (eds): Readings in the economics of taxation, London: Allen \& Unwin.

Happé, R. - Gribnau H. (2007): The Netherlands national report: Constitutional limits to taxation in a democratic state: The Dutch experience. Michigan State Journal of International Law 15: 417-459.

Lütge, F. (1961): Finanzgeschichte. Tübingen: J.C.B. Mohr

Murphy, L. - Nagel, T. (2004): The myth of ownership. Taxes and justice. Oxford:Oxford University Press.

Musgave, P. B. (2001): Revisiting the theory of international income taxation. Principal paper: Sovereignty entitlement, and cooperation in international taxation. Brooklyn Journal of International Law 26: 1335.

Musgrave, R. A. (1959): The Theory of Public Finance: A Study in Political Economy, McGraw-Hill.

Musgrave, R. A. - Musgrave, P. B. (1972): Inter-nation equity. In: Bird, R. M. - Head, J. G. (eds): Modern Fiscal Issues: Essays in Honor of Carl S. Shoup. Toronto: University of Toronto Press.

Musgrave, R. A. (2008): Public finance. Durlauf, S. N. - Blume, L. E. (eds): The New Palgrave Dictionary of Economics. Basingstoke: Plagrave, pp. 1057-58.

Румянцев, А.М. - Богомолов, О.Т. et al. (eds; 1982): Политическая экономия, Том 2 Москва: Экономика, р. 323.

Scalia, A. (1989): The rule of law as a law of rules. The University of Chicago Law Review 56(4): 1176. 
Schanz, G. von (1896): Der Einkommensbegriff und die Einkommensteuergesetze. FinanzArchiv 13: 1-87.

Seligman, E. R. A. (1959): Public Finance. Encyclopaedia of the Social Sciences, Vol. 11-12, New York: McMillan, p. 640.

Shavell, S. (1993): The optimal structure of law enforcement. Journal of Law and Economics 36(1): 255-287.

Simons, H. C. (1970): The comprehensive definition of income. In: Houghton, R.W. (ed.): Public finance; Selected readings. Harmondsworth: Penguin, pp. 38-45.

Smith, A. (1981 [1776]): The Wealth of Nations. Indianapolis: Liberty Fund.

Timberg, S. (1946): Corporate fictions; Logical, social and international implications. Columbia Law Review 46(4): 533-580.

Wade, H.W.R. (1941): The concept of legal certainty. A preliminary skirmish. The Modern Law Review 4(3): 183-199.

Weber, M. (1922): Wirtschaft und Gesellschaft. Tübingen: J.C.B. Mohr.

Wittfogel, K. A. (1962): Die orientalische Despotie. Eine vergleicheinde Untersuchung totaler Macht. Köln/Berlin. 